\title{
Rural Tourism Development in Cameron Highlands: Indigenous Community's Perception towards Socio- Cultural and Economic Impacts
}

Siti Sabariah Ismail, Zuliah Abd Hamid, Siti Nur Syazwani Mohd Fakri, Liana Hazirah Ab Aziz

To Link this Article: http://dx.doi.org/10.6007/IJARBSS/v11-i13/8516

DOI:10.6007/IJARBSS/v11-i13/8516

Received: 18 November 2020, Revised: 15 December 2020, Accepted: 10 January 2021

Published Online: 28 January 2021

In-Text Citation: (Ismail et al., 2021)

To Cite this Article: Ismail, S. S., Hamid, Z. A., Fakri, S. N. S. M., \& Aziz, L. H. A. (2021). Rural Tourism Development in Cameron Highlands: Indigenous Community's Perception towards Socio-Cultural and Economic Impacts. International Journal of Academic Research in Business and Social Sciences, 11(13), 206-221.

Copyright: (c) 2021 The Author(s)

Published by Human Resource Management Academic Research Society (www.hrmars.com) This article is published under the Creative Commons Attribution (CC BY 4.0) license. Anyone may reproduce, distribute, translate and create derivative works of this article (for both commercial and non-commercial purposes), subject to full attribution to the original publication and authors. The full terms of this license may be seen at: http://creativecommons.org/licences/by/4.0/legalcode

Special Issue: Beyond 2021 and COVID-19 - New Perspective in the Hospitality \& Tourism Industry, 2021, Pg. 206 - 221 


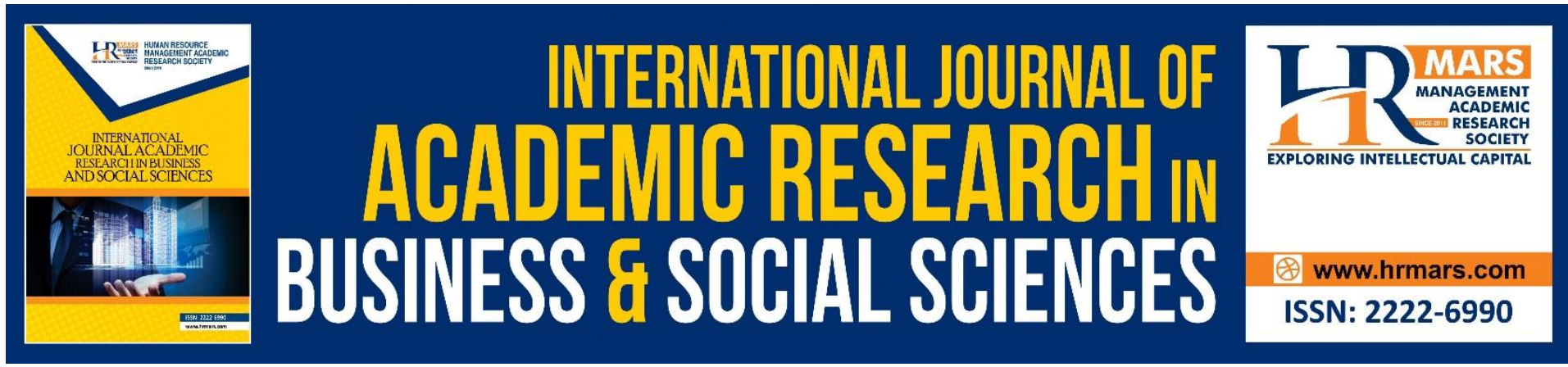

\title{
Rural Tourism Development in Cameron Highlands: Indigenous Community's Perception towards Socio-Cultural and Economic Impacts
}

\author{
Siti Sabariah Ismail, Zuliah Abd Hamid, Siti Nur Syazwani Mohd \\ Fakri, Liana Hazirah Ab Aziz
}

Faculty of Hotel and Tourism Management, Universiti Teknologi MARA, Puncak Alam

Campus, 42300, Selangor, Malaysia

\begin{abstract}
The development of tourism industry in Cameron Highlands has brought impacts directly or indirectly to the local community in general, including the minority group of indigenous people. The production of tourism and its operations are largely monopolized by the private entities. Such practices are highly focused on mass tourism, adventure tourism, and 'greenwashed' ecotourism, with many having detrimental environmental and local community consequences. The main purpose of the study is to analyse the indigenous community's perception on socio-cultural and economic impacts as a result of rural tourism development in Cameron Highlands. The research employed quantitative analysis using the stratified random sampling method in the village of Sungai Ruil and Sungai Chohong indigenous community. A total of 270 respondents were involved. Research findings showed that the development of the tourism industry has created positive impacts on these two aspects for the indigenous communities in Sungai Ruil and Sungai Chohong. The results however revealed that in comparison, the socio-cultural impacts are greater than the economic impacts. This research will educate the responsible firms on the socio-economic impacts of rural tourism development towards the indigenous community and the sustainability of these indigenous culture.
\end{abstract}

Keywords: Economic Impacts, Indigenous Community, Perception, Rural Tourism, SocioCultural Impacts.

\section{Introduction}

The World Tourism Organization defined rural tourism as a tourism product "that gives to visitors a personalized experience, a taste of physical and human environment of countryside and as far possible, allow then to participate in the activities, tradition, and lifestyles of local people" (Aref and Gill, 2009). Dyer, Aberdeen, and Schuler (2003) described that the development of tourism had given multiple impacts to the community which gains advantages by increasing the employment and cultural understanding, wealth, as well as community wellbeing. Previous research found that rural tourism creates a variety of 
potential advantage such as increase in job opportunities, population, and enhancement in social which resulted in rural socio-economic to regenerate. Meanwhile, Alison (2004) stated that with the recognition of Thailand's indigenous community, tourists are becoming more treasured for their culture, which based on five fundamental dimensions that are observing their way of life, climate, authenticity, personal interaction, and informal education.

Issues associated with the indigenous community have been discussed by many scholars and nongovernmental organizations. However, according to Jamiran and Seow (2013) constraints in hunting and harvesting forest products are further incensing the situation, especially for the indigenous community's economy and culture. This is a big concern and will present longterm challenges in terms of preserving traditional culture, affecting the future generation who will inherit the political, economic, and social future (Jamiran and Seow, 2013). Ryan (2005) discussed that indigenous culture has often had to adjust their values and norms for tourists, who are normally Western-oriented.

Tourism development tends to give a negative effect on indigenous life. The impact can cause the decline in indigenous culture to the majority of indigenous people in certain areas, and it can also lead to negative impacts on the ecological environment and animal habitats (Smith, 2003). Based on the frequency of intrusion in the social life of indigenous communities, as the number of tourist increased, the indigenous communities felt it could change and ruin their culture, particularly if their living space became a popular attraction for tourists (Greenwood, 1989; Moowforth and Munt, 1998).

Generally, the indigenous communities are endangered community by development. Sahdan, Che Rose, and Ahmad, (2009) found that the Bateq, which is one of the sub-ethnic Orang Asli, has undergone a change of culture as a result of ecotourism activities in the national park. The changes fell into four cultural aspects of language, food, clothing, and craftsmanship. Furthermore, Aminudin Mohamed, a Coordinator of Adult Classes for Parents of the Orang Asli and Peribumi Students (KEDAP) in their research showed that the issue of their retrograde culture, which often related to the growth and education of the indigenous community, is rather slow compared to other cultures. The indigenous community lacks interest in education and the practice of education, and does not concern the development around them, which is simpler and close to the wilderness. Therefore, they also lack selfdiscipline and hardly find the aim of their lives on a regular basis to contact other people with lower self-esteem.

Therefore, this study seeks to analyse the indigenous community's perception on the socioeconomic impact of rural tourism development in Cameron Highlands. Two major research questions were outlined for the study: (a) To investigate the socio-cultural impact of rural tourism development on the indigenous community, and (b) To examine the economic impact of rural tourism development on the indigenous community in Cameron Highlands.

\section{Literature Review}

\section{Indigenous Community in Cameron Highlands}

The World Health Organization (WHO) defines indigenous populations as communities within or attached to traditional habitats or ancestral territories which are geographically distinct (WHO, 2011). Indigenous tourism generally refers to "activities in which indigenous people 
participate directly either through control and/or through making their culture function as the basis of the attraction" (Hinch and Prentice, 2004).

Aboriginal people or indigenous communities in Malaysia are a minority race as it represents only 0.63 percent of the total population in Malaysia. In December 2010, there were around 36,658 Orang Asli families in Peninsula Malaysia (JAKOA, 2011; Norfariza Hanim Kasim, 2008). In the same year, there were also 852 Orang Asli villages in Malaysia. These villages are categorized into three based on their location, level of economic development, and the basic amenities. Around $61 \%$ of the Orang Asli live on the outskirts of the cities, $38 \%$ in the interiors and only $1 \%$ in the cities (JAKOA 2011). The majority sub-ethnic is from Senoi followed by Proto Malay and Negrito or Semang (Azuwani, Noor, Cheong, Kok, Aw, Nadiah, and Abdul, 2013). Orang Asli are the only indigenous community pioneer party that remains in Malaysia before being invaded by other colonial powers from different countries.

Cameron Highlands is a well-known destination for its Malaysian agro-tourism and ecotourism, both domestically and internationally. It is also a residence for about 60,000 indigenous people clustered in 28 villages that resides around the mountainous region (JHEOA, 2010) where some are either directly or indirectly involved in tourism activities. Rural development in Cameron Highlands will have an effect on the indigenous people who are living there originally. The indigenous community encounters both pleasant and unpleasant results of tourism, either directly or indirectly, or their involvement is essential to manage the impacts effectively and to acquire the benefits generated by tourism activities in that area (Cole, 2006).

\section{Indigenous Community's Perception}

Perception is influenced by different factors, including the intensity and physical dimensions of the stimulus such activity of the sensory organs as effects of previous stimulation; the experience of the subject; factors of attention such as readiness to respond to stimuli; and motivation and emotional state of the subject (The Columbia Electronic Encyclopedia, 2007).

In relation to perception, Besculides, Lee and McCormick (2002), pointed out that social and economic factors such as group connection, long-term living in an area and economic reliance on tourism would influence the expectations and attitudes of the indigenous community towards the growth of tourism. Nunkoo and Ramkissoon (2002) added that resident perceptions of the social and cultural impacts of tourism growth in Mauritius indicated that respondents generally supported tourism industry development, mainly because they depend on the tourism industry.

Contrary to the view of development proponents, the conservative developers claimed that tourism operations can have negative impacts, such as traffic congestion, inflation, and environmental issues. All groups agreed, however, that tourism can still generate more employment opportunities (Perez and Nadal, 2005).

Thus, when positive benefits are greater than negative ones, residents of the local community are more credible in supporting the development of tourism. Meanwhile, Nunkoo and Ramkissoon (2010) built an integrated resort model for community support to study residents of Mauritius. The results found that three factors influencing the resident support for 
incorporating a resort on the premises: community satisfaction, local economy, and attitudes towards the environment. The concerns with the perceptual investment growth of these variables have a direct impact on whether the citizens support the development of tourism.

\section{Socio-Cultural Impacts}

Murphy (1985) defines tourism as a socio-cultural impact for both the guest and the host. These impacts can bring different systems and behaviours in value, thus threatening indigenous identity. Nevertheless, by fostering pride in cultural traditions and helping to prevent urban migration by creating local jobs, impacts on tourism can be optimistic and seen. The socio-cultural impacts attributed to tourism can be analysed from two perspectives: indirect effects that function through significant economic and cultural changes in society, and direct individual encounters (Pearce, 1982).

There are some positive socio-cultural impacts to the indigenous community. Based on Norlida, Ridzuan, Siti, Abdul and Doris (2012), this situation has prompted the community to improve its ability to communicate with the outsiders about their culture, especially tourists who are also proud of their culture and who are more interested in meeting outsiders or tourists. Besides this, tourism will help develop new entertainment and leisure facilities (Tovar \& Lockwood, 2008), explain the sense of cultural identity within the society, as well as encouraging the restoration and preservation of traditional arts, music, and crafts (Haralambopoulos and Pizam, 1996; Jaafar, Rasoolimanesh, and Ismail, 2015; Kim, 2002), and motivating the local community to take pride in their culture (Jaafar et al., 2015; McGehee, Andereck, and Vogt, 2002).

While these benefits are likely to be most acute in rural areas and for indigenous peoples, tourism can also have detrimental effects on the social and cultural life of a community, particularly when tourist visitation rates are growing (Bennett, Lemelin, Koster, and Budke, 2012). Indigenous leaders are sometimes inclined to shun tourism development in fear of the effects of tourism on their communities, particularly for the children who can be easily influenced and want to live in a foreign lifestyle (Kousis, 1989). Furthermore, differences in the customs and values of tourists and the local community can lead to conflict or misunderstanding and sometimes even violence (Wu, Wall, and Tsou, 2014).

According to Ryan (1991), it was found that the indigenous people started to disapprove or restrict their activities in the area. This rejection was also reported by Mercer (1994), who indicated that disruptions to indigenous communities' social life occurred as the number of tourist arrivals grew. Indigenous communities often feared the influx of tourists might change their culture and ruin it, especially if their settlements became a popular tourist attraction (Greenwood, 1989; Moowforth and Munt, 1998).

Many indigenous leaders see tourism as a disruptive force in their communities, especially children, who may be attracted and influence the more modern foreign lifestyle, and who ultimately look to leave the community because of the demand for modernisation (Kousis, 1989). Thus, the growth of a local tourism sector often persuades young men to abandon their plots of land to work as guides and porters in the tourism industry. 


\section{Economic Impacts}

In relation to economic impacts, Kuvan and Akan (2005) indicated that many rural communities have acquired tourism as a new economic development strategy to alleviate the economic difficulties. The vast majority of tourism economic impact studies focused on employment opportunities, living standards, income a society receives from tourism activities and living costs (Kim, 2002). Additionally, a research by Norlida et al. (2012), has identified that the advancement of the tourism industry has resulted in an increase in indigenous incomes in the Cameron Highlands, which is why employment opportunities and family economic growth are increasing. Besides, Dyer et al. (2003) has acknowledged that the growth of tourism has brought different impacts to the local community, which benefits from job opportunities and enhanced cultural understanding, prosperity, and well-being. This finding was supported by studies conducted by several researchers (Husbands, 1998; Madrigal, 1993; Lankford and Howard, 1994).

Consequently, subsistence farming and fishing are often the majority of economic activities for indigenous people, tourism has the potential to greatly boost their household income. In addition, tourism development can provide monetary incentives for indigenous communities to pursue their traditional crafts and arts. With hotels and other tourist accommodation providers offering a lucrative local produce market (Latip, Rasoolimanesh, Mostafa, Mastura, Marzuki, and Umar 2018). With regards to homestay in Cameron Highlands, there are negative impacts on the indigenous community. "Although the homestay program was a good move, we do not get any money from it...in fact, the biggest homestay in our village is being operated by an outsider...how we will get any income? We may get some money only if the tourists buy our handicrafts when they are brought here by the travel agents." (Tok Batin (village headman), Sungai Ruil, Cameron Highlands, Malaysia, 2011).

Nevertheless, the growth of tourism can have an impact on the price of essential goods and, more specifically, on increased prices or costs of houses. The increasing financial need for family support among indigenous peoples, which has changed the attitudes and lifestyles of this group from a simple lifestyle to a more complicated lifestyle in which people have to leave their jobs (Norlida et al., 2012). Tourism activities also result in higher living costs, higher property prices, overcrowding and road congestion, higher demand and competition for resources and amenities and higher prevalence of substance use and other antisocial behaviours, especially among younger generations (Brunt and Courtney, 1999; Deery et al., 2012; Haralambopoulos and Pizam, 1996; Ko and Stewart, 2002; Látková and Vogt, 2012; Liu and Var, 1986; Tosun, 2002).

\section{Methodology}

\section{Research Design}

This study is designed to investigate the socio-economic impact of rural tourism development towards indigenous community in Cameron Highlands. This research employs quantitative method. Data was collected from both primary and secondary sources to analyse tourism impact on indigenous people. 


\section{Population and Sample}

This research focused on Cameron Highlands district because Cameron Highlands is one of the popular destinations in the tourism industry and where the indigenous community resides. The estimated number of populations of this study is 1,762 indigenous people in Cameron Highlands district (Cameron Highlands District and Land Office, 2015). There are several villages in Cameron Highlands, namely, Kampung Orang Asli Sungai Ubi, Kampung Orang Asli Sungai Ruil, Kampung Orang Asli Sungai Tiang, Kampung Orang Asli Sungai Chohong, and Kampung Orang Asli Sungai Kabuk. However, this study was conducted in two villages which are Kampung Orang Asli Sungai Ruil and Sungai Chohong with a population of 950 people. The reason for this selection is because Kampung Orang Asli Sungai Ruil has the highest population and the two villages are closer to the tourist attractions than the other villages, which is located within $20 \mathrm{~km}$ from the centre of tourist activity. A total of 274 samples were chosen from the population and this amount is based on the sample size table, as suggested by Krejie and Morgan (1970). Findings from the questionnaire will be reliable in terms of the impact of development on these indigenous people. The list villages and population are listed below:

Table 1: Distribution of Orang Asli Population

\begin{tabular}{cccccc}
\hline No & Village & $\begin{array}{c}\text { Head Villager's } \\
\text { Name }\end{array}$ & $\begin{array}{c}\text { Sub } \\
\text { Ethnic }\end{array}$ & $\begin{array}{c}\text { Distance from } \\
\text { Tanah Rata } \\
\text { (kKm) }\end{array}$ & $\begin{array}{c}\text { Total } \\
\text { Communities }\end{array}$ \\
\hline 1 & $\begin{array}{c}\text { Kampung Orang Asli } \\
\text { Sungai Ruil }\end{array}$ & Head Village A & Semai & 8 & 813 \\
\hline 2 & $\begin{array}{c}\text { Kampung Orang Asli } \\
\text { Sungai Ubi }\end{array}$ & Head Village B & Semai & 14 & 378 \\
\hline 3 & $\begin{array}{c}\text { Kampung Orang Asli } \\
\text { Sungai Tiang }\end{array}$ & Head Village C & Semai & 36 & 327 \\
\hline 4 & $\begin{array}{c}\text { Kampung Orang Asli } \\
\text { Sungai Chohong }\end{array}$ & Head Village D & Semai & 14 & 137 \\
\hline 5 & $\begin{array}{c}\text { Kampung Orang Asli } \\
\text { Sungai Kabuk }\end{array}$ & Head Village E & Semai & 36 & $\mathbf{1 , 7 6 2}$ \\
\hline
\end{tabular}

Sources: Cameron Highlands District Office, 2015

Table 2: Selected Villages of Orang Asli

\begin{tabular}{cccccc}
\hline No & Village & $\begin{array}{c}\text { Head Villager's } \\
\text { Name }\end{array}$ & $\begin{array}{c}\text { Sub } \\
\text { Ethnic }\end{array}$ & $\begin{array}{c}\text { Distance } \\
\text { from Tanah } \\
\text { Rata (Km) }\end{array}$ & $\begin{array}{c}\text { Total } \\
\text { Communities }\end{array}$ \\
\hline 1 & $\begin{array}{c}\text { Kampung Orang Asli } \\
\text { Sungai Ruil }\end{array}$ & Head Village A & Semai & 8 & 813 \\
\hline 2 & $\begin{array}{c}\text { Kampung Orang Asli } \\
\text { Sungai Chohong }\end{array}$ & Head Village D & Semai & 14 & 137 \\
\hline Total & & & & & 950 \\
\hline
\end{tabular}




\section{Research Instrument}

The survey instrument used in this study is a structured questionnaire. The research sample constitutes of 274 responses. The questionnaire is divided into four sections. The first section used a nominal scale, and the other three sections used a two-point Likert scale ( $1=$ Disagree and 2 = Agree). A two-point Likert type scale is used for respondents to rate these 20 items instead of the five-point Likert type scale. These items were formulated into a simple version to enable a better understanding by the indigenous respondents of the answer needed by the questionnaires in this research (Norlida et al., 2012). The questionnaire was provided to the local community in bilingual (Malay and English) so that the indigenous respondents can better understand the answer needed by the questionnaires.

Part A contained questions relating to the demographic characteristics of the respondent. Part B consists of question-related to socio-cultural impact on the indigenous population. Part C comprises of questions related to the economic impact toward indigenous people in Cameron Highland. The last part, Part D consist of questions related to the indigenous community perception of rural tourism development. For the pilot study, the researchers distributed 30 questionnaires at the indigenous community at Mah Meri Culture Village in Carey Island, Selangor to verify the validity of the questionnaire content and to test the respondents' understanding of the questions and usefulness of the scale to make assessment. As for data processing and analysis, all the data was transformed by using the Statistical Package for Social Sciences (SPSS Version 24.0). This research used Cronbach alpha (Cronbach, 1951) to test reliability of the pilot study. To analyse the dataset, the descriptive analysis is used to find the frequencies, mean, percentage, standard deviation. Finally, multiple regression analysis was used to find the results and hypothesis were tested.

\section{Result and Analysis}

For this study, 300 questionnaires were self-distributed at both Indigenous Villages in Cameron Highlands. 257 questionnaires were distributed to the villages of Kampung Orang Asli Sungai Ruil and 43 questionnaires were distributed to the villages at Kampung Sungai Chohong. The distributions were based on $50 \%$ for each village. Out of 300 questionnaires, 270 questionnaires were returned and usable. The responds rates for the questionnaires' were $90 \%$ that reflects for both villages. The questionnaires were distributed from 19th December to 20th December 2019 at both locations starting from 3:00 pm to 9:00 pm with the help from the Head of the Village (Tok Batin) and his assistant. During the gathering of data, any difficulties were able to solve immediately which eliminates language barriers and misunderstanding. Besides, the researchers were there to monitor and assist the process. It took only two days because the Head of the Villages manage to gather the available populations as they return from work and were also asked to distribute to the family members. All questionnaires' were collected immediately as they finish answering the survey.

A set of 270 questionnaires were gathered and analysed. The demographic characteristics includes gender, household status, age group, marital status, religion, educational level, and average monthly salary. All of the respondents are from the Semai ethnic group $(n=270)$. Table 3indicated the outcomes of the demographics. The survey implies that percentage of female respondents (68.1\%) were greater than male respondents (31.9\%). Most of the respondent was a member of a household with $83.3 \%(n=225)$, meanwhile the head of the 
household was $16.7 \%(n=45)$. This is because one household only has one head and many members of the household. Majority of the respondents are between the ages of 21-30 years old. Therespondent's marital status is single with $51.9 \%$ which slightly higher than respondents that are married with $44.4 \%$. Common religion of the respondent's is worshiping their ancestor with $29.6 \%$. The highest education levels of the respondents were from the secondary school (33.3\%). Most of respondent estimated average salaries were bellow RM 440 with $33.7 \%$ as they are self-employed (small entrepreneur).

Table 3: Demographic Profile of Respondents

\begin{tabular}{|c|c|c|}
\hline Variables & Frequency & Percent (\%) \\
\hline \multicolumn{3}{|l|}{ Gender } \\
\hline Male & 86 & 31.9 \\
\hline Female & 184 & 68.1 \\
\hline \multicolumn{3}{|l|}{ Household Status } \\
\hline Head of household & 45 & 16.7 \\
\hline Member of household & 225 & 83.3 \\
\hline \multicolumn{3}{|l|}{ Age Group } \\
\hline $18-20$ & 65 & 24.1 \\
\hline $21-30$ & 69 & 25.6 \\
\hline $31-40$ & 48 & 17.8 \\
\hline $41-50$ & 40 & 14.8 \\
\hline 51 and Above & 48 & 17.8 \\
\hline \multicolumn{3}{|l|}{ Marital Status } \\
\hline Single & 140 & 51.9 \\
\hline Married & 120 & 44.4 \\
\hline Widow & 10 & 3.7 \\
\hline \multicolumn{3}{|l|}{ Religion } \\
\hline Ancestor & 80 & 29.6 \\
\hline Islam & 50 & 18.5 \\
\hline Christian & 76 & 28.1 \\
\hline Hindu & 7 & 2.6 \\
\hline Others & 57 & 21.1 \\
\hline \multicolumn{3}{|l|}{ Education Level } \\
\hline Never schooled* & 60 & 22.2 \\
\hline Informal Education** & 17 & 6.3 \\
\hline Primary school & 38 & 14.1 \\
\hline Secondary school & 90 & 33.3 \\
\hline University or College & 65 & 24.1 \\
\hline \multicolumn{3}{|c|}{ Average Salary (Monthly) } \\
\hline Below RM440 & 91 & 33.7 \\
\hline Below RM550 & 40 & 14.8 \\
\hline RM501 - RM1,000 & 33 & 12.2 \\
\hline RM1,001 - RM1,500 & 44 & 16.3 \\
\hline $\mathrm{RM} 1,501-\mathrm{RM} 2,000$ & 62 & 23.0 \\
\hline
\end{tabular}

* Never attend school at all

** Education based on home schooling or tuition 


\section{Result and Analysis \\ Socio-Cultural Impacts}

The total mean score for the socio-cultural impact is 1.8139 (SD=0.21305) which also shows all questions in this section are at the agreed level. Most of the indigenous communities agreed that the tourism industry has contributed towards cultural conservation and restoration with $(87.0 \%)$ agreed and $(13.0 \%)$ disagreed. Whereas $(85.9 \%)$ of respondents agreed that rural tourism has increased the number of tourists met by the indigenous community, meanwhile (14.1\%) disagreed. It also shows that the indigenous community feels pride in their culture (84.1\%). It showed that (80.7\%) of respondents agreed and (19.3\%) disagreed high season tourism has been contributing to crowding and inflation issues. Based on Table 4 showed that (78.9\%) rural tourism does not disturb the indigenous community's daily life. (78.5\%) of respondents accepted that rural tourism increases the ability of storytelling about their culture meanwhile (21.5\%) disagreed. Respondent agreed (78.1\%) that rural tourism impacted on socio-culture of the indigenous community by changes in their lifestyle and others (21.9\%) disagreed. Besides that, rural tourism does not disturb indigenous community practices on religion and culture with $(77.8 \%)$ agreed and $(22.2 \%)$ disagreed. Table 4 exhibits the summary of social-cultural impact's mean value and standard deviation.

Table 4: Socio-cultural Impacts

\section{Part B: Socio-Culture Impacts}

\begin{tabular}{ccc}
$\begin{array}{c}\text { Agree } \\
(\%)\end{array}$ & $\begin{array}{c}\text { Disagree } \\
(\%)\end{array}$ & $\begin{array}{c}\text { Mean / } \\
\text { Standard } \\
\text { Deviation }\end{array}$ \\
\hline
\end{tabular}

\begin{tabular}{|c|c|c|c|}
\hline \multicolumn{4}{|c|}{ Mean $=1.8139, \mathrm{SD}=0.21305$} \\
\hline Changes the lifestyle of the indigenous community & $\begin{array}{c}211 \\
(78.1)\end{array}$ & $\begin{array}{c}59 \\
(21.9)\end{array}$ & $\begin{array}{c}1.78 \\
(0.414)\end{array}$ \\
\hline Does not disturb the indigenous people's daily living & $\begin{array}{c}213 \\
(78.9)\end{array}$ & $\begin{array}{c}57 \\
(21.1)\end{array}$ & $\begin{array}{c}1.79 \\
(0.408)\end{array}$ \\
\hline $\begin{array}{l}\text { Increases the number of outsiders (tourists) met by the } \\
\text { indigenous community }\end{array}$ & $\begin{array}{c}232 \\
(85.9)\end{array}$ & $\begin{array}{c}38 \\
(14.1)\end{array}$ & $\begin{array}{c}1.86 \\
(0.348)\end{array}$ \\
\hline Feelings of pride by indigenous people in their culture & $\begin{array}{c}227 \\
(84.1)\end{array}$ & $\begin{array}{c}43 \\
(15.9)\end{array}$ & $\begin{array}{c}1.84 \\
(0.366)\end{array}$ \\
\hline $\begin{array}{l}\text { Contribution of tourism industry for cultural conservation } \\
\text { and restoration }\end{array}$ & $\begin{array}{c}235 \\
(87.0)\end{array}$ & $\begin{array}{c}35 \\
(13.0)\end{array}$ & $\begin{array}{c}1.87 \\
(0.336)\end{array}$ \\
\hline $\begin{array}{l}\text { Increases the ability of storytelling about the culture of } \\
\text { indigenous people }\end{array}$ & $\begin{array}{c}212 \\
(78.5)\end{array}$ & $\begin{array}{c}58 \\
(21.5)\end{array}$ & $\begin{array}{c}1.79 \\
(0.411)\end{array}$ \\
\hline $\begin{array}{l}\text { No disturbance in the practice of indigenous people's own } \\
\text { religion and culture }\end{array}$ & $\begin{array}{c}210 \\
(77.8)\end{array}$ & $\begin{array}{c}60 \\
(22.2)\end{array}$ & $\begin{array}{c}1.78 \\
(0.416)\end{array}$ \\
\hline $\begin{array}{l}\text { Tourism during the high season contributes to issues such } \\
\text { as crowding, inflation and etc }\end{array}$ & $\begin{array}{c}218 \\
(80.7)\end{array}$ & $\begin{array}{c}52 \\
(19.3)\end{array}$ & $\begin{array}{c}1.81 \\
(0.395)\end{array}$ \\
\hline
\end{tabular}

\section{Economic Impacts}

The total mean score for the economic impact is 1.7630 (SD=0.16855) which also shows that most of the questions related to economic impact are at the agreeable level. This showed that respondent agreed rural tourism does increase the economics of indigenous community $(90.7 \%)$, provides more jobs for the indigenous community $(90.4 \%)$ and generate income of indigenous community (87.4\%). Aside from that, rural tourism also attracts outsiders to do 
business within nearby indigenous village area which (84.4\%) of respondents agreed and (15.6\%) disagreed. However, respondents agreed that rural tourism has impacted increased prices and basic needs (80.0\%), thus increased the cost of living in Cameron Highlands (78.1\%). Moreover, (58.9\%) of respondents agreed rural tourism earnings do not cause indigenous children to drop out of school at a young age. However, respondents disagreed $(59.6 \%)$ that rural tourism impacted on the increased price of house or land. Table 5 displays the summary of the economic impact's mean value and standard deviation.

Table 5: Economic Impacts

\begin{tabular}{lccc}
\hline Part C: Economic Impacts & $\begin{array}{c}\text { Agree } \\
\text { (\%) }\end{array}$ & $\begin{array}{c}\text { Disagre } \\
\mathbf{e} \\
(\mathbf{\%})\end{array}$ & $\begin{array}{c}\text { Mean / } \\
\text { Standard } \\
\text { Deviation }\end{array}$ \\
\hline Provides more jobs for indigenous people & 244 & 26 & 1.90 \\
& $(90.4)$ & $(9.6)$ & $(0.295)$ \\
\hline Income generation through tourism Industry & 236 & 34 & 1.87 \\
& $(87.4)$ & $(12.6)$ & $(0.332)$ \\
\hline Increases the economics of indigenous people & 245 & 25 & 1.91 \\
& $(90.7)$ & $(9.3)$ & $(0.290)$ \\
\hline Increases the prices of house/land & 109 & 161 & 1.40 \\
& $(40.4)$ & $(59.6)$ & $(0.491)$ \\
\hline Earnings from tourism lure children at this community & 159 & 111 & 1.59 \\
to drop out of school at an early age & $(58.9)$ & $(41.1)$ & $(0.493)$ \\
\hline Attract outsiders to do business within nearby areas & 228 & 42 & 1.84 \\
& $(84.4)$ & $(15.6)$ & $(0.363)$ \\
\hline Tourism increased the cost of living in Cameron & 211 & 59 & 1.78 \\
Highland & $(78.1)$ & $(21.9)$ & $(0.414)$ \\
\hline Increases the prices of basic needs & 216 & 54 & 1.80 \\
& $(80.0)$ & $(20.0)$ & $(0.401)$ \\
\hline
\end{tabular}

\section{Indigenous Community's Perception}

The total mean score for the indigenous community's perception is 1.8333 (SD=0.26047) which also shows that most of the respondents agreed level on questions related to the indigenous community's perception. It showed that (85.6\%) of respondents agreed that the development has provided advantages and benefits to the indigenous community precisely with employment opportunities. Most of the respondents (85.6\%) feel happy with the rise in tourist numbers coming to their settlements. (82.6\%) of respondents agreed that tourism growth in Cameron Highlands had numerous economic and social-cultural effects on the indigenous people in the neighbourhood areas. Thus, (79.6\%) of respondents agreed that tourism has improved indigenous community behaviours with their family and society. Table 6 indicates the summary of the indigenous community perception section's mean value and standard deviation. 
Table 6: Indigenous Community's Perception

\begin{tabular}{|c|c|c|c|}
\hline Part D: Indigenous Community Perception & $\begin{array}{l}\text { Agree } \\
(\%)\end{array}$ & $\begin{array}{l}\text { Disagree } \\
\text { (\%) }\end{array}$ & $\begin{array}{l}\text { Mean / } \\
\text { Standard } \\
\text { Deviation }\end{array}$ \\
\hline \multicolumn{4}{|l|}{ Mean $=1.8333, \mathrm{SD}=0.26047$} \\
\hline $\begin{array}{l}\text { The development of tourism in Cameron Highlands has had } \\
\text { several impacts (economic, and social-cultural) on the } \\
\text { indigenous people within the surrounding areas }\end{array}$ & $\begin{array}{c}215 \\
(79.6)\end{array}$ & $\begin{array}{c}55 \\
(20.4)\end{array}$ & $\begin{array}{c}1.79 \\
(0.404)\end{array}$ \\
\hline $\begin{array}{l}\text { This development has also provided advantages and } \\
\text { benefits to the indigenous people especially with regard to } \\
\text { employment opportunities }\end{array}$ & $\begin{array}{c}231 \\
(85.6)\end{array}$ & $\begin{array}{c}39 \\
(14.4)\end{array}$ & $\begin{array}{c}1.85 \\
(0.352)\end{array}$ \\
\hline $\begin{array}{l}\text { Feel happy with the increased number of tourist arrivals to } \\
\text { their settlements }\end{array}$ & $\begin{array}{c}231 \\
(85.6)\end{array}$ & $\begin{array}{c}39 \\
(14.4) \\
\end{array}$ & $\begin{array}{c}1.85 \\
(0.352) \\
\end{array}$ \\
\hline $\begin{array}{l}\text { Tourism has improved my behaviours with my family and } \\
\text { society }\end{array}$ & $\begin{array}{c}223 \\
(82.6)\end{array}$ & $\begin{array}{c}47 \\
(17.4)\end{array}$ & $\begin{array}{c}1.83 \\
(0.380)\end{array}$ \\
\hline
\end{tabular}

\section{Hypotheses Testing}

The hypothesis is to show the relationship between socio-economic impact and the indigenous community's perception. Thus, multiple regressions were used for relationship testing and two hypotheses were analysed for the study. The first and the second hypotheses were used to determine if:

$\mathrm{H}_{1}$ : There is a significant relationship between socio-cultural impact and perception of the indigenous community on rural tourism development.

$\mathrm{H}_{2}$ : There is a significant relationship between economic impact and perception of the indigenous community on rural tourism development.

Table 7: Summary of the Hypotheses Results of Multiple Regression

\begin{tabular}{lccccc}
\hline & \multicolumn{2}{c}{$\begin{array}{c}\text { Unstandardized } \\
\text { Coefficients }\end{array}$} & $\begin{array}{c}\text { Standardized } \\
\text { Coefficients }\end{array}$ & t & Sig. \\
\cline { 2 - 6 } & B & Std. Error & Beta & & \\
\hline (Constant) & -0.053 & 0.133 & & -0.395 & 0.693 \\
Social Cultural Impact & 0.576 & 0.062 & 0.471 & 9.227 & 0.000 \\
Economic Impact & 0.477 & 0.079 & 0.309 & 6.045 & 0.000 \\
\hline
\end{tabular}

Based onTable 7, it indicates that there is a significant relationship between both socio-culturaland economic impacts with perception of the indigenous community on rural tourism development. Beta coefficient value $(\beta=.471, p<0.05)$ produced by social cultural impact indicates that it has the most impact on the perception of the indigenous community on rural tourism development. Then, followed by economic impact $(\beta=.309, p$ $<0.05)$.

\section{Conclusion}

Cameron Highlands is one of the famous tourist attractions in Malaysia and known to have a high number of indigenous people. The increasing number of visitors to Cameron Highlands is the reason for the development of tourism activity and facilities. Thus, findings from this 
research shows that there are socio-cultural and economic impacts towards the indigenous community due to the development of rural tourism.

From the study, the majority of the respondents agreed that the development of rural tourism has socio-cultural impacts on the indigenous community at Cameron Highlands. This is shown in table 4 where the mean socio-cultural impact score from rural development to the indigenous community was 1.8139. In addition, the community has the highest agreement $(87.0 \%)$ on the fact that tourism industry brings contribution for cultural conservation and restoration to the society. Therefore, from the impacts it shows that tourism can be an opportunity for them to maintain their culture, feeling proud and create awareness to others on the uniqueness of their culture. Apart from that, the influx of people/tourists does not alter and disrupt this community's life. Even from a religious standpoint, (77.8\%) accepted that tourist arrivals did not hinder or prohibit them from engaging in religious practices and culture. This ensures these groups can still uphold their traditional practices.

This is consistent with the research shown in Taman Negara, Malaysia, where the indigenous people believe tourism has important socio-cultural implications, such as communications and tourism activities (Ramachandran, Shuib, Rusli, and Som 2006). Fox (1977) suggests that tourism's social and cultural effect is the manner in which tourism creates a shift in value systems, individual behaviour, family relationships, and group attitudes, safety rates, moral behaviour, artistic expressions, traditional ceremonies, and community organizations. However, Faulkner and Tideswell (1997) stated that the socio-cultural impacts of tourism should be monitored continuously in order to increase the benefits of tourism at the destination.

Moving on, the majority of the respondents agreed that there are economic impacts towards rural tourism development in Cameron Highlands. This is illustrated in Table 5 where the total mean score for the economic impact is 1.7630. Apart from that, the indigenous people had a high agreement on that tourism increases the economics (90.7\%). Furthermore, previous studies have identified several positive economic impacts of tourism on destination communities, including higher family incomes and more employment opportunities (Andereck, Valentine, Knopf, and Vogt, 2005; Rasoolimanesh and Jaafar, 2016). For indigenous people, tourism can alleviate poverty, diversify economic activities, and increase the demand sale of indigenous goods and services (Bennett et al., 2012; Dyer et al., 2003; Wu et al., 2014). However, these positive effects must certainly be viewed in view of the adverse economic impacts, which may include high housing costs, higher land prices, and property taxes, global rises in goods and services prices, and the likelihood of low payment to indigenous peoples for employment in the tourism industry (Andereck et al., 2005; Brunt and Courtney, 1999; Látková and Vogt, 2012).

Finally, future research is needed in testing new variables that gives impact to the indigenous community due to tourism development, especially on the environmental impact. There is a real need to embark tourism research on other indigenous communities at other attractions, so to get a better understanding on how tourism has an overall impact towards the communities' socio-economy. Apart from that, limitations encountered are on the research setting which must be changed due to landslides in Cameron Highlands. Furthermore, the 
indigenous as the respondents are mostly illiterate, therefor the research process is affected, and it takes more time to complete the survey. To conclude, there are socio-cultural and economic impacts towards the indigenous community due to the development of rural tourism in Cameron Highlands. Responsible firm should therefore be aware of the impacts so as not to harm the indigenous community considering that it is a valuable tourism product to be sustained.

\section{Corresponding Author}

Siti Sabariah Ismail. Faculty of Hotel and Tourism Management, Universiti Teknologi MARA Cawangan Selangor, Puncak Alam Campus, 42300, Selangor, Malaysia.

E-mail: sitis377@uitm.edu.my

\section{References}

Alison, J. M. (2004). Tourists' appreciation of Maori culture in New Zealand. Tourism Management,25, 1-15.

Andereck, K. L., Valentine, K. M., Knopf, R. C., and Vogt, C. A. (2005). Residents' perceptions of community tourism impacts. Annals of Tourism Research, 32(4), 1056-1076. doi:10.1016/j.annals.2005.03.001

Aref, F., and Gill, S. S. (2009). Rural tourism development through rural cooperatives. Nature and Science, 7(10), 68-73.

Azuwani, A. R., Noor, K. K., Cheong, Y. Z., Kok, C. C., Aw, N. S. L., Nadiah, M. S., and Abdul, R. K. (2013). Body Fat Percentage Distribution of an Orang Asli Group (Aborigines) in Cameron Highlands, Malaysia. Malaysian Journal of Nutrition, 19(2), 205-214

Bennett, N., Lemelin, R. H., Koster, R., andBudke, I. (2012). A capital assets framework for appraising and building capacity for tourism development in aboriginal protected area gateway communities. Tourism Management, 33(4), 752-766.

doi:10.1016/j.tourman.2011.08.009

Besculides, A., Lee, M. E., and McCormick, P. J. (2002). Resident's perceptions of the cultural benefits of tourism. Annals of Tourism Research, 29(2), 303-319. https://doi.org/10.1016/S0160-7383(01)00066-4

Brunt, P., and Courtney, P. (1999). Host perceptions of sociocultural impacts. Annals of Tourism Research, 26(3)493-515. doi:10.1016/s0160-7383(99)00003-1.

Cameron Highlands District and Land Office Official Portal (2015). Sejarah Cameron Highlands. Retrieved from http://pdtchighlands.pahang.gov.my/index.php/2012-0904-08-40-50/latar-belakang/sejarah-cameron-highlands

Cole, S. (2006).Information and empowerment: The keys to achieving sustainable tourism. Journal of Sustainable Tourism, 14(6), 629-644. https://doi.org/10.2167/jost607.0

Cronbach, L. J. (1951). Coefficient alpha and the internal structure of tests. Psychometrika, 16, 297-334.

Dyer, P., Aberdeen, L., and Schuler, S. (2003). Tourism impacts on an Australian indigenous community: A Djabugay case study. Tourism Management, 24(1), 83-95. doi:10.1016/s0261-5177(02)00049-3

Faulkner, B., and Carmen, C. (1997). A framework for monitoring community impacts of tourism. Journal of Sustainable Tourism, 5(1), 3-28., doi:10.1080/09669589708667273.

Fox, J. J. (1977). Harvest of the palm: Ecological change in Eastern Indonesia. Harvard University Press. doi:10.4159/harvard.9780674331884. 
Greenwood, D. J. (1989). Culture by the pound: An anthropological perspective on tourism as cultural commoditization. The Anthropology of Tourism, 2, 171-185.

Haralambopoulos, N., and Pizam, A. (1996). Perceived impacts of tourism: The case of Samos. Annals of Tourism Research, 23(3), 503-526.

Jaafar, M., Rasoolimanesh, S. M., and Ismail, S. (2015). Perceived sociocultural impacts of tourism and community participation: A case study of Langkawi Island. Tourism and Hospitality Research, 8(2), 123-134, doi: 10.1177/1467358415610373.

JAKOA. (2011). Pelan Strategik Kemajuan Orang Asli, 2011-2015, Jabatan Kemajuan Orang Asli.

Jamiran, M. N. S., and Seow, T. W. (2013). Socio-economic development of the orang asli in Malaysia: Universiti Tun Hussein Onn Malaysia (UTHM). Retrieved fromhttp://eprints.uthm.edu.my/id/eprint/5826/1/14._mohd_nur_syufaat.pdf

Kousis, M. (1989). Tourism and the family in a rural Cretan community. Annals of Tourism Research, 16(3), 318-332. doi:10.1016/0160-7383(89)90047-9.

Krejcie, R. V., and Morgan, D. W. (1970). Determining sample size for research activities. Educational and Psychological Measurement, 30(3), 607-610. doi: 10.1177/001316447003000308

Kuvan, Y., and Akan, P. (2005). Residents attitudes toward general and forest-related impacts of tourism: The case of Belek, Antalya. Tourism Management, 26(5), 691-706. doi:10.1016/j.tourman.2004.02.019.

Lankford, S. V., and Howard, D. R. (1994). Developing a tourism impact attitude scale. Annals of Tourism Research,21(1),121-139.https://doi.org/10.1016/0160-7383(94)90008-6

Látková, P., and Vogt, C. A. (2012). Residents' attitudes toward existing and future tourism development in rural communities. Journal of Travel Research, 51(1), 50-67., doi:10.1177/0047287510394193.

Madrigal, R. (1993). A Tale of Tourism in Two Cities. Annals of Tourism Research 20:336353.1995 Personal Values, Traveler Personality Type, and Leisure Travel Style. Journal of Leisure Research 27, 125-142.

McGehee, N. G., Andereck, K. L., and Vogt, C. A. (2002). An examination of factors influencing resident attitudes toward tourism in twelve Arizona communities. Paper presented at the Proceedings of the 33rd Annual Travel and Tourism Research Association Conference, Arlington, VA.

Mercer, D. (1994). Native peoples and tourism: conflict and compromise. Global tourism: The next decade, Oxford: Butterworth-Heinemann.

Moowforth, M., and Munt, I. (1998). Tourism and sustainability: New tourism in the third world. Routledge: London.

Murphy, K. J. (1985). Corporate performance and managerial remuneration. Journal of Accounting and Economics, 7(1-3), 11-42. doi: 10.1016/0165-4101(85)90026-6

Norlida, H. M. S., Ridzuan, O., Siti, H. M. I., Abdul, H. J., and Doris, P. S. (2012). The indigenous community's perception of tourism development in the Cameron Highlands, Malaysia: A preliminary study. Journal of Tourism, Hospitality, and Culinary Arts, 4, 77-87.

Pérez, E. A., and Nadal, J. R. (2005). Host community perceptions a cluster analysis. Annals of Tourism Research, 32(4), 925-941. doi: 10.1016/j.annals.2004.11.004

Ramachandran, S., Shuib, A., Yacob, M. R., and Som, M. A. P. (2006). Determining responsible tourism indicators: A case of Taman Negara, Malaysia. Proceeding of the International Conference of Sustainable Tourism, Barbados. 
Rasoolimanesh, S. M., and Jaafar, M. (2016). Residents' Perception toward Tourism Development: a Pre-Development Perspective. Journal of Place Management and Development, 9(1) 91-104., doi:10.1108/jpmd-10-2015-0045.

Ryan, C. (2005). Events and artifacts. In C. Ryan and M. Aicken (Eds.), Indigenous tourism. The commodification and management of culture (pp. 151-154). Amsterdam: Elsevier

Sahdan, Z., Che Rose, R. A., and Ahmad, H. (2009). Cultural Changes of Bateq People in the situation of Ecotourism in National Park. e-Bangi (4) 2009: 159-169. Retrieved from http://ejournal.ukm.my/ebangi/article/view/22030

Smith, M. (2003). Issues in cultural tourism studies. London: Routledge. The Columbia Electronic Encyclopedia, 6th Ed. (2007), Columbia University Press, New York. Retrieved from https://www.worldcat.org/title/columbia-electronic-encyclopedia6th-edition/oclc/746941797

Tosun, C. (2002). Host perceptions of impacts: A comparative tourism study. Annals of Tourism Research, 29(1), 231-253. doi:10.1016/S0160-7383(01)00039-1

Wu, T. C., Wall, G., and Tsou, L. Y. (2014). Serious tourists: A proposition for sustainable indigenous tourism. Current Issues in Tourism, 20(13), 1-20. doi:10.1080/13683500.2014.970143 